Journal of Organometallic Chemistry, 81 (1974) 7-15

(C) Elsevier Sequoia S A , Lausanne - Printed in The Netherlands

COORDINATION COMPLEXES OF BIS(2,2-DIMETHYL-3,5-HEXANEDIONATO)ZINC WITH ORGANOZINC-OXYGEN AND -NITROGEN COMPOUNDS. CRYSTAL STRUCTURE OF THE COMPLEX FORMED WITH PHENYLZINC PHENOXIDE

\title{
J BOERSMA
}

Laboratory for Organic Chemistry, State University of Utrecht, Utrecht (The Netherlands)

A L SPEK

Laboratory for X-ray Crustallography, State Universtty of Utrecht, Utrecht (The Netherlands)

J G NOLTES*

Inst:tute for Organic Chemistry TNO Utrecht (The Ne'herlands)

(Received May 30th, 1974)

\section{Summary}

In benzene solution organozinc-oxygen compounds of the type (RZnOR'), and bis(2,2-dimethyl-3,5-hexanedionato)zinc ( $\left.\mathrm{Zn}(\mathrm{pac})_{2}\right)$ form coinplexes of the composition $\mathrm{RZnOR}^{\prime} \mathrm{Zn}(\mathrm{pac})_{2}\left(\mathrm{R}=\mathrm{Et}, \mathrm{Ph} ; \mathrm{R}^{\prime}=\mathrm{Me}, \mathrm{Ph}\right)$, which un bouling benzene exist as dissociating dimers. Interaction of (EtZnNPh $)_{2}$ with $\mathrm{Zn}(p a c)_{2}$ affords a crystall ine complex $\mathrm{Zn}\left(\mathrm{NPh}_{2}\right)_{2} \mathrm{Zn}(\text { pac })_{2}$, which is fully dissociated in bolling benzene. The crystal and molecular structure of $\left[\mathrm{PhZnOPh} \cdot \mathrm{Zn}(\mathrm{pac})_{2}\right]_{2}$ has been determined. The material crystallızes in the monoclinuc space group $P 2_{1} / c$, with two dimeric units in a unit cell with dimensions $a=12.90(1), b=$ 11.92(1), $c=23.21(1) \AA$ and $\beta=125.10(5)^{\circ}$. The structure was solved by direct and Fourier methods and refined by block diagonal least squares to a final $R$ value of $12.9 \%$. The structure contains an elght-membered $\mathrm{Zn}_{4} \mathrm{O}_{4}$ ring formed by alternating zinc and oxygen atoms. This ring is bridged twice by the oxygen atoms of the two PhZnOPh moleties. The dimeric structure contains four- and six-coordinate zinc atoms and two-, three-, and four-coordunate oxygen atoms.

\section{Introduction}

An X-ray study has revealed that solid bis(2,4-pentanedionato)zinc, $\mathrm{Zn}(\mathrm{acac})_{2}$, is associated to trumers via $\mathrm{Zn}-\mathrm{O}$ coordınate bonds [1] These bonds

* Author to whom correspondence should be addressed at the Institute for Organc Chemistry TNO. Croesestrat 79 (P O B 5009), Utrecht. The Netherlands 
are not very strong as is apparent from the observation that $\mathrm{Zn}(\mathrm{acac})_{2}$ is monomerıc in boulng benzene [2] and that mononuclear complexes with well-defined stoechiometry are formed with appropriate ligands such as pyrid ine [3], 2,2bipyridy] [2] and TMED [2]. We have previously described novel trunuclear phenylzinc $\beta$-diketonate complexes in which a bis $(\beta$-diketonato $) z i n c$ molecule is coordinated to two phenylzinc $\beta$-diketonate molecules [4]. The proposed structure, containung one central six-coordinate and two four-coordinate zınc atoms, has been confirmed by a sungle crystal X-ray study [5].

Organozinc compounds RZnX are generally associated va intermolecular zinc-heteroatom bonding both in the solid and in solution. The known coord!nation behaviour of zinc bis( $\beta$-diketonates) and of monoorganozinc compounds $\mathrm{RZnX}[6,7]$ has led us to investigate the possiblity of complex formation between these two types of compounds. The results of this study are presented in this paper which includes the results of a single crystal X-ray study of one of the complexes isolated.

Results

Formation of complexes

Microwave titration [8] of the organozinc-oxygen compounds [EtZnOPh $]_{4}$ [9], [PhZnOPh $]_{4}[6]$ and [EtZnOMle $]_{4}[10]$ with bis(2,2-dimethyl-3,5-heyanedionato)zinc, $Z n(p a c)_{2}$, in benzene solution revealed the formation of compleyes of the type $\mathrm{RZnOR}^{\prime} \mathrm{Zn}(\mathrm{pac})_{2}$ When $\mathrm{Zn}(\mathrm{pac})_{2}$ was brought into reaction with these organozunc-osygen compounds on a pieparative scale, in every case the corresponding $1 / 1$ complex RZnOR' $\mathrm{Zn}(\mathrm{pac})_{2}$ was isolated in good yield. Mlolecular weight determinations. in bollng benzerie showed all three compleses to be dissociatıng dimers $\left[R Z n C \cdot R^{\prime} Z n(p a c)_{2}\right]_{2} . O$ ly one set of absorptions attributable to 2,2-dimethyl-3,5-h 2 yanedionate groups appeared in the PM1R spectra of the pyridine- $d_{5}$ solution at ambient temperaiure. In the IR spectra only absorptions belonging to chelating $\beta$-diketonate ligands were present.

The reaction of [EtZnNPh, $]_{2}[11]$ with $\mathrm{Zn}(\text { pac })_{2}$ falled to yield $\mathrm{EtZnNPh}_{2}$ $\mathrm{Zn}(\mathrm{pac})_{2}, \mathrm{Zn}\left(\mathrm{NPh}_{2}\right)_{2} \cdot \mathrm{Zn}(\mathrm{pac})_{2}$ being isolated instead. An identical product was isolated from the $1 / 1$ reaction of $\mathrm{Zn}\left(\mathrm{NPh}_{2}\right)_{2}$ with $\mathrm{Zn}(\mathrm{pac})_{2}$. A molecular weight determination of this comples indicated virtually complete dissociation in bolling benzene.

\section{Molecular structure of $\left[P h Z_{n} O P h Z_{n}(p a c)_{2}\right]_{2}$}

In order to obtain more detaled information about the molecular structure of this type of comples, a single crystal X-ray study of [PhZnOPh $\left.\mathrm{Zn}(\mathrm{pac})_{2}\right]_{2}$ has been carried out. Two dimer molecules are present in the unit cell. Fig. 1 shows the schematic structure, and Fig. 2 a stereopair drawing Bond distances and bond angles are given in Tables 1 and 2 respectively. The structure contains an eight-membered $\mathrm{Zn}_{4} \mathrm{O}_{4}$, nng, formed by $\mathrm{Zn}(1), \mathrm{O}(3), \mathrm{Zn}\left(2^{\prime}\right), \mathrm{O}\left(5^{\prime}\right), \mathrm{Zn}\left(1^{\prime}\right)$, $O\left(3^{\prime}\right), \mathrm{Zn}(2)$ and $O(5)$ The zınc-oxygen bond lengths in this ring vary between 2.03 and $2.08 \AA$, a normal value for $\mathrm{Zn}-\mathrm{O}$ coordinate bonds if compared with those reported in the literature, 1 e. $2.09 \AA$ in [MeZnOMe $]_{4}[12], 2038$ to 2.170 $\AA$ in $\mathrm{Zn}_{7} \mathrm{O}_{3}\left(\mathrm{CH}_{3}\right)_{14}[13], 1.962 \bar{A}$ in $\mathrm{Zn}(\mathrm{dpm})_{2}[14]$ and $2.02 \bar{A}$ in $\mathrm{Zn}(\mathrm{acac})_{2}$ $\mathrm{H}_{2} \mathrm{O}$ [15]. The ring is bridged tivice by the four-coordinate oxygen atoms $O(7)$ 


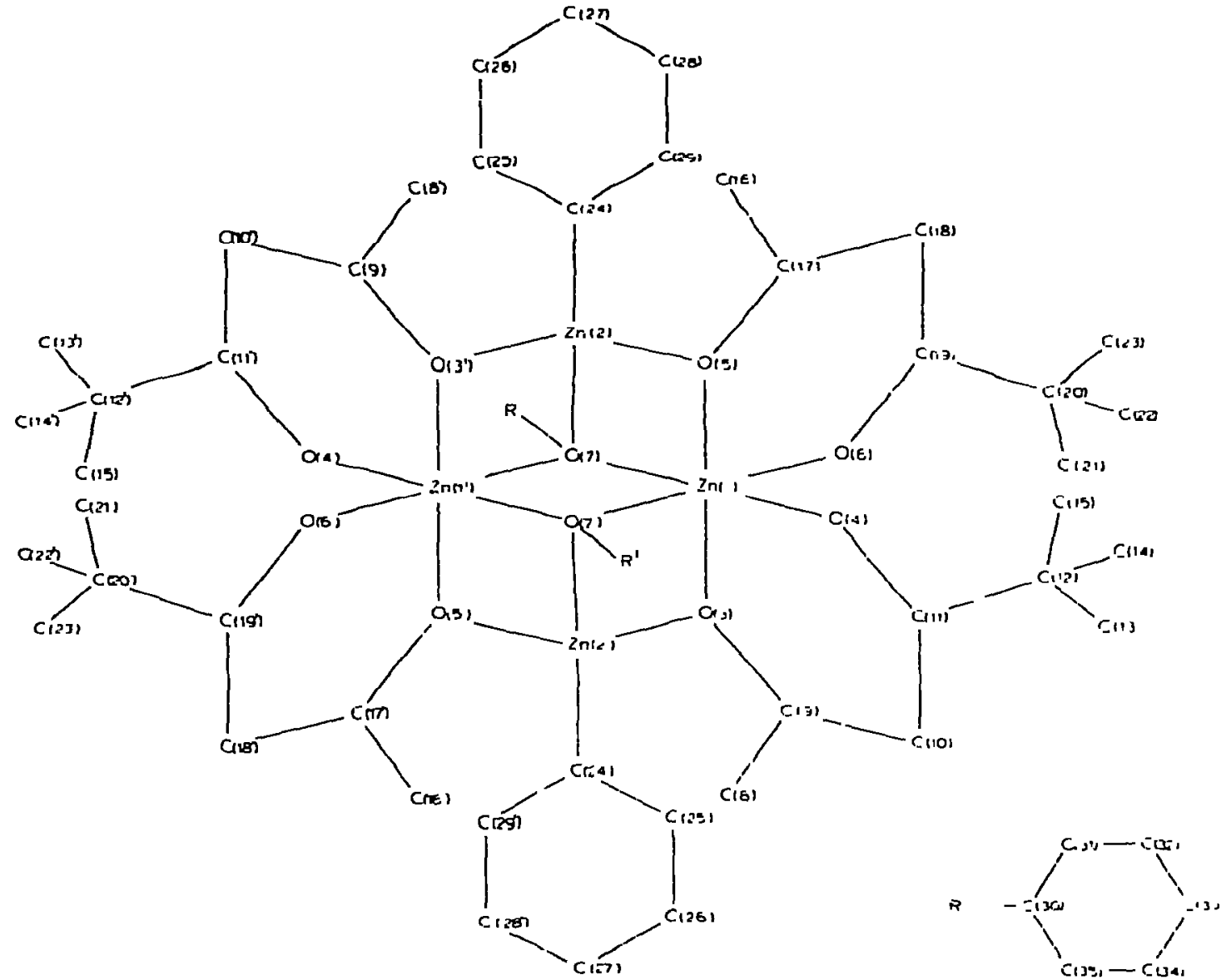

Fig 1 Schematic structure of the [PhZnOPh Zn(pac) 2 I? cumplex

and $\mathrm{O}\left(7^{\prime}\right)$ of the two $\mathrm{PhZnOPh}$ moieties via relatively long zinc-oxygen coordnate bonds ( 2.17 and $2.19 \AA$ ). The $\mathrm{Zn}-\mathrm{O}$ bond lengths in the $\beta$-diketonate nings appear to be independent of the coordination number of the oxygens. For instance the $\mathrm{Zn}(1)-\mathrm{O}(6)$ bond is nearly equal to the $\mathrm{Zn}(1)-\mathrm{O}(5)$ bond although

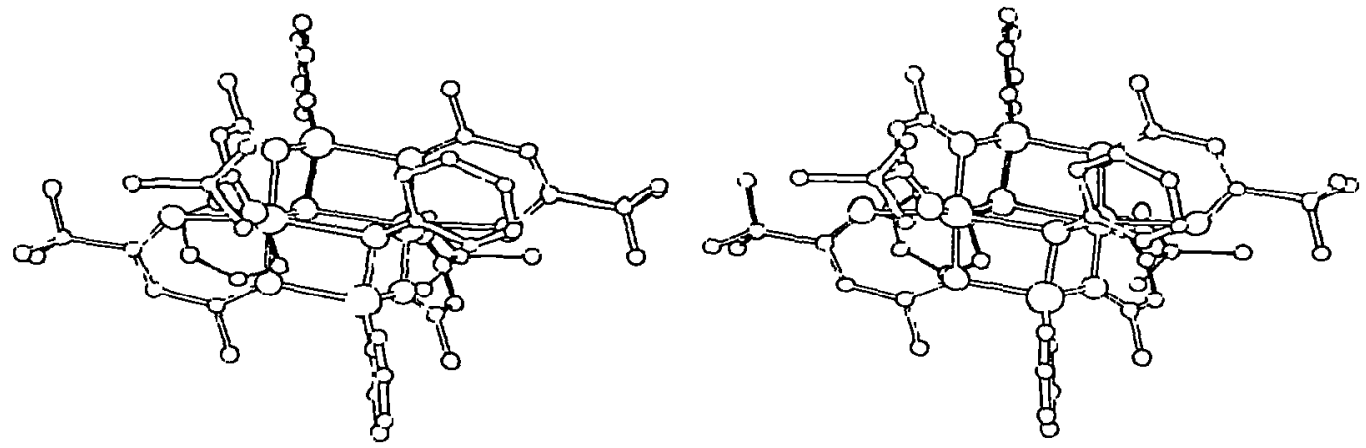

Fig 2 Stereopar drawing of the [PhZnoPh $\mathrm{Zn}(\mathrm{pac})_{2} \mathrm{I}_{2}$ complex 
BOND DISTANCES ( $\&$ ) WITH STANDARD DEVIATIONS

\begin{tabular}{llll}
\hline$Z n(1)-O(3)$ & $208(1)$ & $C(12)-C(15)$ & $150(5)$ \\
$Z n(1)-O(4)$ & $204(2)$ & $C(16)-C(17)$ & $153(3)$ \\
$Z n(1)-O(5)$ & $203(1)$ & $C(17)-C(18)$ & $135(3)$ \\
$Z n(1)-O(6)$ & $203(1)$ & $C(18)-C(19)$ & $138(3)$ \\
$Z n(1)-O(7)$ & $2.20(1)$ & $C(19)-C(20)$ & $151(3)$ \\
$Z n(1)-O(7)$ & $217(2)$ & $C(20)-C(21)$ & $156(4)$ \\
$Z n(2)-O(5)$ & $204(1)$ & $C(20)-C(22)$ & $152(6)$ \\
$Z n(2)-O(7)$ & $204(1)$ & $C(20)-C(23)$ & $149(4)$ \\
$Z n(2)-C(24)$ & $197(2)$ & $C(24)-C(25)$ & $141(3)$ \\
$Z n(2)-O(3)$ & $205(2)$ & $C(24)-C(29)$ & $140(3)$ \\
$O(3)-C(9)$ & $131(3)$ & $C(25)-C(26)$ & $143(4)$ \\
$O(4)-C(11)$ & $129(3)$ & $C(26)-C(27)$ & $144(4)$ \\
$O(5)-C(17)$ & $134(2)$ & $C(27)-C(28)$ & $1414)$ \\
$O(5)-C(19)$ & $130(2)$ & $C(28)-C(29)$ & $138(3)$ \\
$O(7)-C(30)$ & $137(2)$ & $C(30)-C(31)$ & $142(3)$ \\
$C(8)-C(9)$ & $152(3)$ & $C(30)-C(35)$ & $143(3)$ \\
$C(9)-C(10)$ & $134(4)$ & $C(31)-C(32)$ & $138(3)$ \\
$C(10)-C(11)$ & $143(3)$ & $C(32)-C(33)$ & $139(3)$ \\
$C(11)-C(12)$ & $152(4)$ & $C(33)-C(34)$ & $17(9)$ \\
$C(12)-C(13)$ & $153(4)$ & $C(341-C(35)$ & \\
$C(12)-C(14)$ & $159(5)$ & & \\
\hline
\end{tabular}

TABLE 2

BOND ANGLES ( ) WITH STANDARD DEVIATIONS

\begin{tabular}{|c|c|c|c|}
\hline$O(3)-2 n(1)-O(4)$ & $873(6)$ & $O(1)-C(11)-C(12)$ & $1136(18)$ \\
\hline$O(3)-Z n(1)-O(5)$ & $1701(2)$ & $O(5)-C(17)-C(16)$ & $1137(17)$ \\
\hline$O(3)-Z n(1)-O(6)$ & $915(5)$ & $O(5)-C(17)-C(18)$ & $1262(17)$ \\
\hline$O(3)-Z n(1)-O(7)$ & $101,(5)$ & $O(6)-C(19)-C(18)$ & $1237(18)$ \\
\hline$O(3)-\operatorname{Zn}(1)-O\left(7^{\prime}\right)$ & $78 '(5)$ & $O(6)-C(19)-C(20)$ & $1151(16)$ \\
\hline $\mathrm{Zn}(1)-O(3)-C(9)$ & $120 \div(13)$ & $C(30)-O(7)-Z n\left(1^{\prime}\right)$ & $1168(12)$ \\
\hline $\mathrm{Zn}(1)-O(3)-\mathrm{Zn}\left(2^{\prime}\right)$ & $100 \Leftarrow(6)$ & $O(7)-c(30)-c(31)$ & $1202(18)$ \\
\hline$O(4)-\operatorname{Zn}(1)-O(5)$ & $1025 \cdot(6)$ & $O(7)-C(30)-C(35)$ & $1183(16)$ \\
\hline$O(4)-Z n(1)-O(6)$ & $93 \cdot(6)$ & $C(8)-C(9)-C(10)$ & $1175(21)$ \\
\hline$O(1)-\operatorname{Zn}(1)-O(7)$ & $89:(6)$ & $C(9)-C(10)-C(11)$ & $1236(20)$ \\
\hline$O(4)-Z n(1)-O\left(7^{\prime}\right)$ & $1631(2)$ & $C(10)-C(11)-C(12)$ & $1209(20)$ \\
\hline $\mathrm{Zn}(1)-O(4)-\mathrm{C}(11)$ & $125 \leq(12)$ & $C(11)-C(12)-C(13)$ & $1121(25)$ \\
\hline$O(5)-2 n(1)-O(6)$ & $88 \subseteq(5)$ & $C(11)-C(12)-C(14)$ & $1069(28)$ \\
\hline$O(5)-Z n(1)-O(7)$ & $77 \subseteq(5)$ & $C(11)-C(12)-C(15)$ & $1079(24)$ \\
\hline$O(5)-\operatorname{Zn}(1)-O\left(7^{\prime}\right)$ & $91 \equiv(6)$ & $C(13)-C(12)-C(1.4)$ & $981(22)$ \\
\hline$Z n(1)-O(5)-Z n(2)$ & $102 \varepsilon(6)$ & $c(13)-c(12)-c(15)$ & $1157(30)$ \\
\hline $\operatorname{Zn}(1)-O(5)-C(17)$ & $125+(11)$ & $C(14)-C(12)-C(15)$ & $1157(32)$ \\
\hline$O(6)-Z n(1)-O(7)$ & $166 \varepsilon(2)$ & $C(16)-C(17)-C(18)$ & $1200(1 \pi)$ \\
\hline$O(6)-\operatorname{Zn}(1)-O\left(7^{\prime}\right)$ & $965(5)$ & $C(17)-C(18)-C(19)$ & $1272(18)$ \\
\hline $\mathrm{Zn}(1)-O(6)-C(19)$ & $1281(11)$ & $C(18)-C(19)-C(20)$ & $1211(17)$ \\
\hline$O(7)-Z n(1)-O\left(7^{\prime}\right)$ & $843(5)$ & $C(19)-C(20)-C(21)$ & $1135(20)$ \\
\hline$Z n(1)-O(7)-Z n(2)$ & $972(5)$ & $C(19)-C(20)-C(22)$ & $1085(22)$ \\
\hline $\operatorname{Zn}(1)-O(7)-C(30)$ & $1258(11)$ & $C(19)-C(20)-C(23)$ & $1119(25)$ \\
\hline $\operatorname{Zn}(1)-O(7)-\operatorname{Zn}\left(1^{\prime}\right)$ & $957(5)$ & $C(21)-C(20)-C(22)$ & $1085(32)$ \\
\hline$Z n(1)-O(7)-Z n(2)$ & $977(6)$ & $C(21)-C(20)-C(23)$ & $1038(24)$ \\
\hline$O(5)-Z n(2)-O(7)$ & $815(5)$ & $C(22)-C(20)-C(23)$ & $1107(29)$ \\
\hline$O(5)-Z n(2)-C(24)$ & $1193(7)$ & $C(25)-C(24)-C(29)$ & $1208(19)$ \\
\hline$O(5)-Z n(2)-O\left(3^{3}\right)$ & $9+9(6)$ & $C(24)-C(25)-C(26)$ & $1240(22)$ \\
\hline $\operatorname{Zn}(2)-O(5)-C(17)$ & $131+(9)$ & $C(24)-C(29)-C(28)$ & $1178(21)$ \\
\hline$O(7)-\operatorname{Zn}(2)-C(24)$ & $1310(5)$ & $C(25)-C(26)-C(27)$ & $11 \pm 1(23)$ \\
\hline$O(7)-\operatorname{Zn}(2)-O\left(3^{2}\right)$ & $825(5)$ & $C(26)-C(27)-C(28)$ & $1237(25)$ \\
\hline $7 n(2)-O(7)-C(30)$ & $1179(10)$ & $C(27)-C(28)-C(29)$ & $1196(26)$ \\
\hline$C(24)-2 n(2)-O(3)$ & $1326(6)$ & $c(31)-c(30)-c(35)$ & $1214(17)$ \\
\hline $\mathrm{Zn}(2)-C(24)-C(25)$ & $1216(16)$ & $C(30)-C(31)-C(32)$ & $1217(21)$ \\
\hline $\operatorname{Zn}(2)-C(24)-C(29)$ & $1175(14)$ & $c(30)-C(35)-C(34)$ & $1150(17)$ \\
\hline$C(9)-O(3)-Z n\left(2^{\prime}\right)$ & $1355(10)$ & $C(31)-C(32)-C(33)$ & $1184(20)$ \\
\hline$O(3)-C(9)-C(8)$ & $11+4(23)$ & $c(32)-c(33)-C(34)$ & $1203(20)$ \\
\hline$O(3)-C(9)-C(10)$ & $1281(16)$ & $C(33)-C(34)-C(35)$ & $1224(21)$ \\
\hline$O(4)-C(11)-C(10)$ & $125.4(20)$ & & \\
\hline
\end{tabular}


$O(5)$ is three-coordinate and $O(6)$ two-coordinate. The lengths of the $\mathrm{Zn}-\mathrm{O}$ bonds in the eight-membered ring do not differ sıgnificantly from those outside the ring

The $\beta$-diketonate groups are planar with in expermental accuracy but both zunc atoms $\mathrm{Zn}(1)$ and $\mathrm{Zn}\left(1^{\prime}\right)$ are outside these planes. The angle between the plane through $\mathrm{Zn}(1), O(3), O(4)$ and the least squares plane determmed by $O(3)$, $O(4), C(8), C(9), C(10), C(11), C(12)$ amounts to $233^{\circ}$ The angle between the planes determined by $\mathrm{Zn}(1), \mathrm{O}(5), \mathrm{O}(6)$ and $\mathrm{O}(5), \mathrm{O}(6), \mathrm{C}(16), \mathrm{C}(17), C(18)$. $\mathrm{C}(19), \mathrm{C}(20)$, respectively, is $3.3^{\circ}$. A sumilar situation was observed for $\mathrm{Zn}$ (acac), $\mathrm{H}_{2} \mathrm{O}[15]$ and $\mathrm{Zn}$ (benzac), EtOH [16]

\section{Discussion}

The formation of coordination compleses between $\mathrm{Zn}(\mathrm{pac})_{2}$ and the three RZnOR' compounds shows that the $\beta$-diketonate oxygens al e very powerful electron donors. This is undoubtedly caused by the presence of a neighbouring zinc atom which enhances the electron-density at the oxygens Moreover, in solution monomeric $\mathrm{Zn}(\mathrm{pac})_{2}$ contaıns a coordinatıvely unsaturated zınc atom. In this way, a synergic donor-acceptor behavour can be espected. The importance of this synergism is revealed by the observation that, although F.tZnONe is generally unreactive towards oxygen-containing ligands [10], it does fol $\mathrm{m}$ a complex with $\mathrm{Zn}(\mathrm{pac})_{2}$

In solution, the compleses between $\mathrm{Zn}(\mathrm{pac})_{2}$ a $\mathrm{dd} \mathrm{RZnOR}$ ' are rather loosely bound since the molecular weight determinations show dissociation. The PNIK spectra show only one kind of $\beta$-diketonate ligand Similar behaviour in solution is displayed by the trmuclear phenylzinc $\beta$ diketonate compleses [4]

The large electron-donating capacity of $\mathrm{Zn}(\mathrm{pac})_{2}$ is borne out by the cry'stal structure of [PhZnOPh $\left.\mathrm{Zn}(\mathrm{pac})_{2}\right]_{2}$ in which the zinc-oyygen bond lengths in the $\mathrm{Zn}(\mathrm{pac})_{2}$ moieties are independent of the coordination number of the osygen atoms. The high coordination number (four) and the weaker electrondonating power of the phenoyy-group oxygen atoms are in agreement with the relatively great length of their coord inate bonds Electronic influences of the t-butyl and methyl groups of the pac ligands are less important than steric factors, since the oxygens adjacent to the methyl groups, 1 e. $O(5), O(3), O\left(5^{\prime}\right)$ and $O\left(3^{\prime}\right)$ form two $\mathrm{Zn}-\mathrm{O}$ bonds whereas those adjacent to the t-butyl groups form only one. In view of the larger inductive effect of t-butyl groups the opposite would have been expected on electronic grounds. but there may be steric interaction with the phenyl groups bound to zinc

The disproportionation reaction which takes place when $\mathrm{Zn}(\mathrm{pac})_{2}$ is treated with EtZnNPh, may be connected with the fact that the nitrogen atom has only one electron pair avalable for coordination, which precludes the formation of a complex simular to [RZnOR' $\left.\mathrm{Zn}(\mathrm{pac})_{2}\right]_{2}$. A simular disproportionation was observed by Coates and Ridley [10] in the reaction of $\mathrm{MeZnNPh}_{2}$ with pyridine.

\section{Experimental}

\section{General methods}

All manipulations were carried out under nitrogen with rigorous exclusion 
of air and moisture. The organozinc-oxygen and -nitrogen compounds were prepared by publıshed procedures $[9,11]$. Molecular weights were determined by ebullıomerry in benzene. Microwave titrations were carried out in benzene solution, using the apparatus described by Adema and Schrama [8]. NMR spectra were run on Varian HA 100 and T 60 spectrometers using benzene as solvent and TMS as internal reference.

\section{Preparatıon of bis(2, 2-dimethyl-3,5-pentanedıonato)zınc, $\mathrm{Zn}(\text { pac })_{2}$}

$3.7 \mathrm{~g}(10.6 \mathrm{mmole})$ of pivaloylacetone was added with sturring to a solution of $1.6 \mathrm{~g}$ (13 $0 \mathrm{mmole}$ ) of diethylzinc in $15 \mathrm{ml}$ of hexane. After $30 \mathrm{~mm}$ stirring the clear solution was stored overnight at $0^{\circ}$ and the colourless precipitate was fultered off After washing with cold $\left(0^{\circ}\right)$ herane, the product was dried in vacuo Y'ield $41 \mathrm{~g}, \mathrm{~m} . \mathrm{p} .153^{\circ}$. (Found. $\mathrm{Zn}, 18.94 . \mathrm{C}_{10} \mathrm{H}_{20} \mathrm{O}_{i} \mathrm{Zn}$ calcd. $\mathrm{Zn}, 1880{ }^{\circ}$ ) Mol wt. found: 351 at 2 i2 wt $c, c$, no concentration dependence, calcd.: 3478 .

Complex of $Z n(p a c)=$ unth ethylzinc phenoxide A solution of $0.457 \mathrm{~g}$ (1.31 mmole) of $\mathrm{Zn}(\mathrm{pac})_{2}$ was added with stirring to a suspension of $0.246 \mathrm{~g} \mathrm{(1.31}$ mmole) of ethyizınc phenoxide in $10 \mathrm{ml}$ of benzene. The suspension cleared during the addition. After removal of the solvent in vacuo, the residue was recrystallized from hexane, washed whth hesane and dried in vacuo. Yield $0.5 \mathrm{~g}$, m.p. $154^{\circ}$. (Found: $\mathrm{Zn}, 24.43 . \mathrm{C}_{24} \mathrm{H}_{30} \mathrm{O}_{5} \mathrm{Zn}_{2}$ calcd.: $\mathrm{Zn}, 24.42 \%$.) Mol. wt found. 584 and 663 at 0.60 and 1.26 wt. $\%$, respectively, calcd.: 535.5 for monomenc complex

Complex of $Z n(p a c)_{2}$ with phenylanc phenoxide This comples was obtained simularly. M.p. $141^{\circ}$. (Found. $\mathrm{Zn}, 21.18 . \mathrm{C}_{28} \mathrm{H}_{30} \mathrm{O}_{3} \mathrm{Zn}_{2}$ calcd.: $\mathrm{Zn}, 21.01 \%$ ) Mol. wt. found. 665 and 736 at 0.53 and 128 wt. re, respectiveiy, calcd.. 5835 for monomeric comples.

Complex of $Z_{n}(p a c)_{2}$ with ethylzunc methox $d_{e}$ This complex was prepared simuarly. $\mathrm{M}$ p. $142^{\circ}$. (Fi)und: $\mathrm{Zn}, 2812 . \mathrm{C}_{19} \mathrm{H}_{34} \mathrm{O}_{5} \mathrm{Zn}$ calcd.: $\mathrm{Zn}, 2763 \mathrm{C}^{\circ}$.) Mol. wt. found: 531 and 607 at 034 and $0.82 \mathrm{wt} C, c$, respectively. calcd. 4732 for monomeric complex.

Complex of $Z n\left(\right.$ pacis $_{2}$ with zinc diphenvlamide To a solution of $0.7 \mathrm{~g}(286$ mmole) of ethylzinc diphenylamide in $10 \mathrm{ml}$ of benzene, a solution of $0.99 \mathrm{~g}$ ( $285 \mathrm{mmole}$ ) of $\mathrm{Zn}(\mathrm{pac})_{2}$ was added whth stirring. A clear, yellow solution resulted. After 30 min additional stirring the solvent was evaporated in vacuo, leaving a yellow foamy mass. This was crystallized from a $10 / 15$ mixture of hesane and benzene, washed with hesane and dried in vacuo Yield $0.8 \mathrm{~g} ; \mathrm{m} \mathrm{p}$. $140^{\circ}$. (Found $\mathrm{N}, 3.48, \mathrm{Zn}, 172 \mathrm{~S} . \mathrm{C}_{40} \mathrm{H}_{30} \mathrm{~N}_{2} \mathrm{O}_{4} \mathrm{Zn}_{2}$ calcd $\mathrm{N}, 3.47 ; \mathrm{Zn}, 1744^{\circ}$.) Mol. wt. found 505 at 1.03 wt. ${ }_{c}$, no concentratıon dependence, calcd. 5000 for complete dissociation into $\mathrm{Zn}(\mathrm{pac})_{2}$ and $\left[\mathrm{Zn}\left(\mathrm{NPh}_{2}\right)_{2}\right]_{2}$

\section{Cn'stal and molecular structure of the $\left[\mathrm{Ph} Z \mathrm{Z} O \mathrm{OPh} Z n(p a c)_{2}\right]_{2}$ complex}

A crystal with approvimate dumensions $0.33 \times 012 \times 009 \mathrm{~mm}$ was mounted unside a Lindemann capillary. Unit cell parameters were determıned by sungle crystal diffractometry using $\mathrm{Cu} \cdot K_{\alpha},(1.54051 \mathrm{f})$ radiation. The crystal was bult up from two parts with nearly the same orientation As a consequence, in an $\omega$-scan, the reflections were split up with a masimum of 0.5 degree. Intensity data of 2594 reflections up to $\mathrm{z} \theta=100^{\circ}$ were collected with a Nonus three circle diffractometer, using nickel filtered $\mathrm{Cu}-K_{a}(1.5418 \AA)$ radiation. The intensities of 


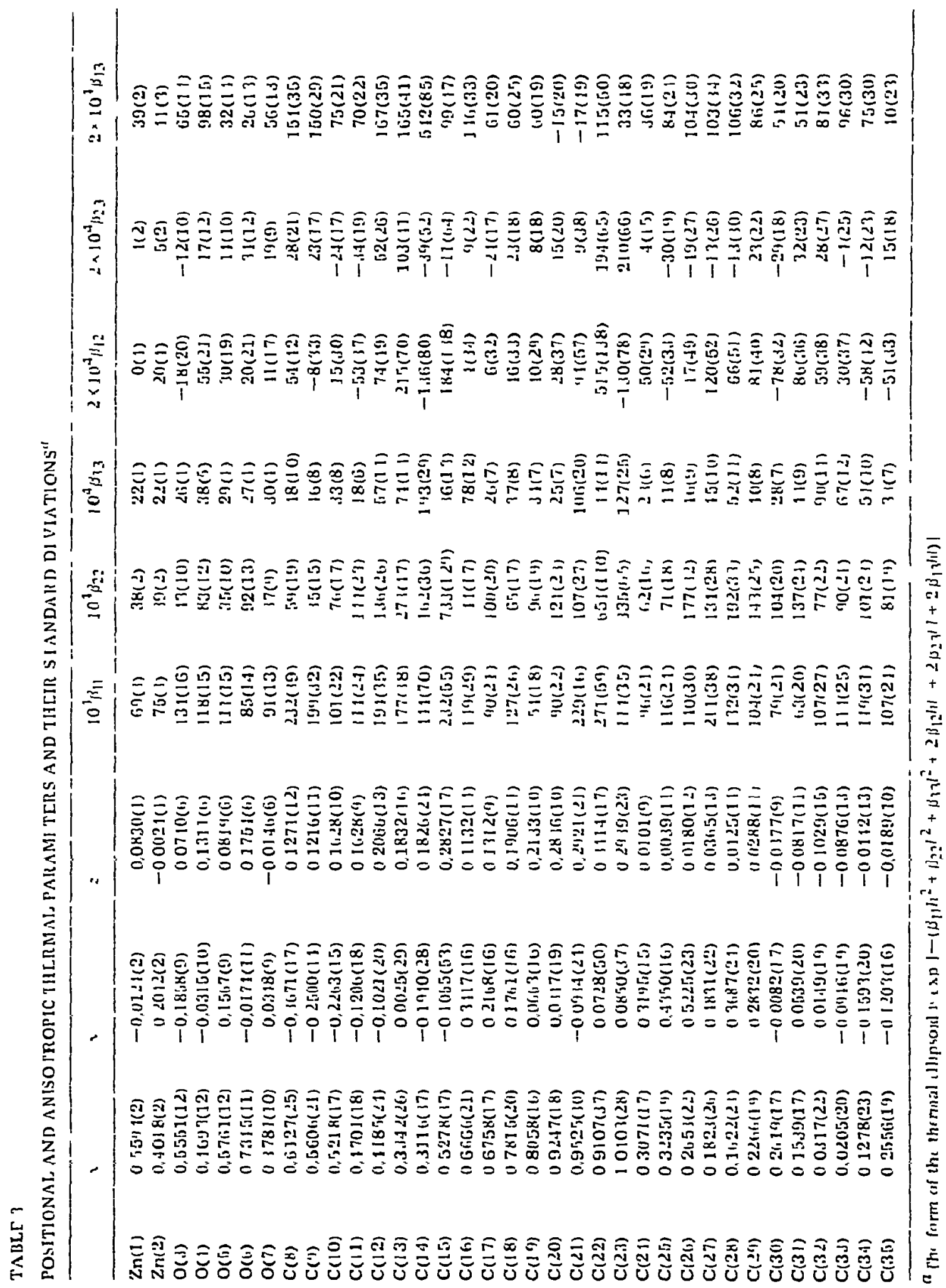


2310 reflections were above background and treated as observed. The scan angle $\left(1.9^{\circ}\right)$ was selected in such a way that the diffracted intensity of both parts of the crystal was collected Lorentz, and polarization, but no absorption corrections were applied to the data $\left(\mu\left(\mathrm{Cu}-K_{\alpha}\right)=236 \mathrm{~cm}^{-1}\right)$. The crystal decomposed durng the data collection The decay in the intensities of two reference reflections (measured every 50 reflectıons), was plotted agaınst tume This plot was used to rescale the intensities by interpolation The max imum rescaling factor amounts to 1.5 .

Crystal data Crystals of [PhZnOPh Zn(pac) $]_{2}$ (mol. wt. 1166.0) are monoclinic with $a=12.90(1), b=11.92(1), c=23.21(1) \AA$ and $\beta=125.10(5)^{\circ}$. The volume of the unt cell is $2919 \AA^{3}$. The space group is unquely determined from the estunctions, $0 k 0 k=2 n+1, h 0 l \cdot l=2 n+1$, as $P 2_{1} / c$. The calculated density of the crystal is $132 \mathrm{~g} / \mathrm{cm}^{3}$ The unit cell contauns two dimers $(Z=2)$.

Structure determinatıon and refinement The crystal structure was solved by direct and Fourier meihnds. The signs of 373 reflections with $E$ values above 1.42 were determined with the program AUDICE [17] After the structure had been solved, only one sign proved to be incorrect. This solution was the one whth the highest figure of merit $\left(\equiv \Sigma_{H, K} \operatorname{sign}\left(E_{H}\right) \times \operatorname{sign}\left(E_{h}\right) \times \operatorname{sign}\left(E_{H-h}\right)\right.$ $E_{r} E_{h} E_{H-K}$ l) out of 64 solutions given by the program A Fourier synthesis calculated with these 373 reflections showed the heavy atom positions and the oxygen coordination clearly and in addition part of the rest of the molecule. All atoms were found in a Fourier synthesis calculated from the 12 atomic positions already found The structure was refined by block diagonal least squares to a final $R$ value of $12.9 \%$. The temperature parameters were ref ined anisotropically. The scattering factors used were those of Cromer et al. [18]. Unit weights were used for all observed reflections Only one reflection was left out, because it apparently suffered from extunction. A linal difference map showed no peaks hgher than $0.7 \mathrm{e}^{-3}$. The coristants applied for the correction for anomalous dispersion of zinc were $\Delta f^{\prime}=-1.73$ and $\Delta^{\prime \prime}=084$ Positıonal and anisotropic thermal parameters are given in Table 3 The thermal parameters of the t-butyl groups are relatively high. The same effect vas found by Coetzer and Boeyens [19] in the crystal structure of bis(2,2,6,6-:etramethylheptane-5-thiolo-3-onato)nickel(II).

Acknowledgements

The authors are indebted to Mr. F Verbeek for able esperimental assistance and to Prof A.F Peerdeman for valuable discussions. The crystal structure investigation was supported by the Netherlands Foundation for Chemical Research (S O.N.).

\section{References}

1 M J Bennet F A Cotton, R Eiss and R C Elder. Nature. (1967) 174

$2 \mathrm{~J}$ Boersma unpublished observations

3 D P Graddon and D G Weeden, Aust J Chem, 16 (1963) 980

$4 \mathrm{~J}$ Boersma. F Verbek and J G Noltes, J Organometal Chem 33 (1971) C53

5 I Boersma i L Speh and J G Voltes, to be publisned

b J Boersma and J G. Noltes, Organozinc Coordination Chemistry. Int Lead Zinc Research Org. New York. 1968 
7 G E Coates, M L H Green and $\mathrm{K}$ Wade, Organometalic Compounds Vol 1, Methuen and Co Ltd. London, 1967 .

8 E.H Adema and $J$ Scbrama, Anal Chem . 37 (1965) 229

$9 \mathrm{~J} G$ Noltes and J Boersma. J. Organometal Chem . $12(1968) 425$

10 G Coates and D Ridley, J Chem Soc, (1965) 1870

$11 \mathrm{~J} G$ Noltes and J Boersma. J Organomelal Chem, 16 (1969) 345

12 H M M Shearer and C B Spencer, Chem Coramun. (1966) 194

$13 \mathrm{NL} \mathrm{L}$ Ziegler and J Weiss. Angew Chem, 82 (1970) 931

1+ F A Cotton and J S Wood, Inorg Chem, 3 (1964) 245

15 E.L Lippert and M.R. Truter, J Chem Soc . (1960) 4996

16 R L Belford N D Chasteen. M A Hitchman, $\mathrm{K}$ Hon, C E Pfluger and I C Paul Inorg Chem 8 (1969) 1312

17 A L Speh, AUDICE, Program for the solution of centrosymmetric crystal structures with direct methods

$18 \mathrm{D} T$ Cromer and J B Mann, Acta Crs stallogr, A2 (1968) 321

$19 \mathrm{~J}$ Coetzer and J C A Boevens. J Cryst Mol Struct , 1 (1971) 277 